\title{
WHY IS IT IMPORTANT TO USE REGIONAL LENSES WHEN WE LOOK INTO CIVIL CONFLICTS IN THE MENA?
}

\begin{abstract}
Samer Hamati
Samerhamati@yahoo.com

$\mathrm{PhD}$ in Economics, School of Economics and Management, University of Minho (Portugal). He was Visiting Researcher in the Department of Political and Economic Studies, University of Helsinki. Expert of Social Capital Rebuilding in Syria, Training and Research Institute of Romania. Senior Researcher of Poverty and Inequality in a UNDP project of Establishing the National Social Welfare Fund in Syria, United Natons Development Programme Projects, Damascus, Syria. External Consultant of set the Food Security Strategy of Syria, Natonal Agricultural Policy Center, Syria. He got a Congratulation Notification approved unanimously from the Portuguese Parliament since he was the firts Syrian students obtaining PhD from Portugal. He has voluntary work experience.
\end{abstract}

\section{Abstract}

Investigating different political and social variables in the Middle East and North Africa (MENA) is receiving more attention between social scientists, particularly in the peace and conflict institutes. This is due to the uniqueness of the region and to the violent conflicts it has witnessed for the last decades. These conflicts become intrastate but transitional, hence transfer into internationalized civil conflicts, and have large externalities exceeding the region borders. These conflicts show the high connectedness between the MENA countries, and recently the Arab Spring affirms the 'contagion effect' of upheavals in the region. Following multidisciplinary approach, this research note is a try to explain how much important it is to study the MENA conflicts from a regional perspective and to present the factors proving the contagion effects there. We hope that when reading this note, the reader will sufficiently understand the regional aspects of the MENA conflicts.

\section{Keywords}

MENA; Contagion Effect; Civil Conflicts

\section{How to cite this article}

Hamati, Samer (2019). "Why is it important to use regional lenses when we look into civil conflicts in the MENA". JANUS.NET e-journal of International Relations, Vol. 10, N.0 2, November 2019-April 2020. Consulted [online] on the date of the last visit, https://doi.org/10.26619/1647-7251.10.2.6 


\title{
WHY IS IT IMPORTANT TO USE REGIONAL LENSES WHEN WE LOOK INTO CIVIL CONFLICTS IN THE MENA?
}

\author{
Samer Hamati
}

\section{Introduction}

For decades the MENA region at large has suffered from violence and experienced civil conflicts leading to a permanent atmosphere of instability. This violence became a normal way of ruling and transferring power since the modern political foundation of the MENA by the end of WWI. Skimming the modern MENA history, one can easily notice that there are shared historical characteristics where conflict trajectories have been similar between the countries. These shared characteristics extend to the political, social, and economic lives, establishing authoritarian and paternalistic regimes in the region and posing particular challenges for transitions and development process. Above all, these characteristics strengthen the links within this region and bring large interventions between the newly established states there. Understanding these interventions is key when studying peace and conflict in the MENA region.

Similar to the global trends, the number of conflicts in the MENA decreased significantly at the beginning of nineties and the region became stable after Kuwait's Liberation Process in 1991. This is clear when skimming the UCDP/PRIO Armed Conflict Database (Uppsala University, 2015). However, the number of conflicts jumps in the new Millennium, mainly due to the occurrence of civil conflicts. More specifically, anti-colonial and interstate conflicts have almost disappeared, and almost all of today's wars are interstate ones but with large international interventions, making them 'internationalized civil wars'. Moreover, these conflicts have been proxy-wars (Marshall, 2016). Pre-1990 conflicts were part of the Cold War with factions receiving support from their allies in Moscow or Washington. Starting from the end of Nineties, the competitors became regional and a cycle of regional proxy warfare, especially between Saudi Arabia and Iran, emerged (Nerguizian and Kasting, 2013). Conflicts in Syria, Iraq, Yemen, Bahrain, and Lebanon are clear examples.

The new waves of post-Arab Spring violence raise the awareness of civil conflicts exploding in the MENA region. It becomes clear that these conflicts are not purely 'civil'; besides, their consequences have gone beyond the MENA borders. Ross et al. (2011) argue that the Arab Spring affirms the 'contagion effect' of upheavals in the region. Based on reviewing the literature, the current note discusses the factors proving this contagion and emphasizing the regional perspective when investigating the civil conflicts in the MENA. We first briefly discuss this term, the MENA, and then we explain some 
characteristics of the MENA civil conflicts that make studying them key to support global peace and prosperity. We later clarify why it is better to look at these conflicts from a regional window. To do so, we follow multidisciplinary approach of analysis using brief social, economic, cultural, familial and historical anecdotal evidence. The note closes with two important notices.

\section{What do we mean by the MENA?}

The term the Middle East appeared centuries after the western concern of this region had increased. Since the Crusades, East, Orient, was identified with Islam and West, Occident, became identical with Christianity. The regions were thus symbolically divided according to two belief systems. Later, in the last quarter of the Eighteenth Century, Europeans referred to the territories controlled by the Islamic Ottoman Empire as the Near East, while Mahan and Chirol used the term the Middle East to call the Gulf of Aden and India in separate articles published in 1902 (Davison, 1960). Due to the political changes after WWI, a need to change the definition of the geographical area referred to as the Middle East appeared, and in March 1921, Winston Churchill, with the help of the Royal Geographical Society, was re-mapping the Middle East from the Bosporus to the western borders of India (Özalp, 2011). Later, this term appeared frequently in international literature.

However, notwithstanding the adoption of the term the Middle East in the international literature, there is no a common agreement on the extension of the geographical areas and the Middle East countries (Johannsen, 2009). Scholars have included different countries, although overlapped, when using this phrase. Many consider it the countries that were occupied by the Ottoman Empire (Tunçdilek, 1971; Brown, 1984; Tibi, 1989), others referred to it as the Islamic countries (Steinbach, 1979), some consider it as limited to the Arabic countries (Hudson, 1976), and a few have included more African countries such as Ethiopia (Davison, 1960). The major part of the recent literature define the MENA region as being made up of the Arabic countries, i.e., the twenty-two countries members of the Arab League, in addition to three non-Arabic countries whose actions contribute to the political and security situations in the MENA region: Turkey, Iran, and Israel, even though these states followed a somewhat different historical trajectory from the Arab states and have different economic structures that in the Arab countries (Owen, 2013).

\section{What does make civil conflicts in The MENA globally important?}

Not only just one factor makes civil conflicts in the MENA with global attention. Conflicts there last and their consequences are large and tragic. Nevertheless, the MENA position is the major reason for this global attention. Due to its strategic geographical position, the MENA region has witnessed many events whose causes and consequences have gone beyond its borders. Barakat (1993: 31) stated that "The centrality of the Arab World in ancient and modern times has qualified it to serve as an important nodal point in human history. It has acted as a passage connecting Asia, Africa, and Europe. It has produced some of the most important intellectual, cultural, and religious contributions of recorded history. It is this position at human and geographic crossroads, and not merely its oil and other resources that makes the Arab World so strategically significant". As a consequence 
of this central geographical position, conflicts have been frequent and characterized by attributes that make them distinctive from those occurring in other regions: sustainability, bloodiness, tragic consequences, and externalities.

Civil conflicts are sustainable in the MENA region. Parallel to internal conflict occurrence, a phenomenon referred to as the 'conflict trap' became more dominant. This trap refers to a situation when a post-civil conflict country falls again in another civil war. Walter (2015) finds strong evidence of a 'conflict trap'; 57\% of all countries that suffered from one civil war during the 1945-2009 period experienced at least one conflict thereafter. Furthermore, she points out that by the 2000 s, $90 \%$ of all civil wars were repeated civil wars. Moreover, Collier (2007) shows that the risk of further conflict in countries emerging from civil war is almost twice as high as it was on the eve of that conflict. Further, Cevik and Rahmati (2015) find that this trap in tighter in the MENA region since countries in the Middle East appear to suffer from a high risk of conflict recurrence without much decline over subsequent years, leading to a sustainable sense of violence and insecurity there. This sustainability is one reason that increases the costs of MENA conflicts.

Civil conflicts in the MENA are costly in both terms: blood and money. The Syrian crisis, which is considered the "worst man-made disaster the world has seen since World War II", according to a UN officer (Al-Hussein, 2017), is recent top evidence for these costs; around $11.5 \%$ of the population were killed or injured in less than five years of conflict (SCPR, 2016). Besides, the region accounts for $40 \%$ of the estimated global total of battle-related deaths since 1946, according to the Uppsala Conflict Data Program. Regarding the high economic costs, Rother et al. (2016) argue that three years of conflicts following the Arabic Spring led to GDP losses of 6 to 15 percentage points in the MENA conflict countries compared with 4 to 9 percentage points worldwide.

These costs, furthermore, are not limited to the region, and other international costs appear. Indeed, the MENA conflicts generate large externalities represented by refugee outflows and energy-price fluctuations. Around two-thirds of current refugees worldwide come from the MENA. ${ }^{1}$ Refugees are not simply the unfortunate by-products of war, but may cause interstate conflicts (Posen, 1996). Salehyan (2008) claims that refugee flows between states increase the likelihood of militarized interstate disputes (MIDs) through two channels: Refugee-receiving states are more likely to initiate MIDs as they intervene to prevent further externalities, and refugee-sending states initiate MIDs as they violate borders in pursuit of dissidents.

Above all, energy-price instabilities are still the clearest externality caused by conflicts occurring in the MENA. This region owns $55 \%$ of global oil reserves (Guidolin and La Ferrara, 2010); and therefore any sort of tension there affects prices, output, employment, and economic growth worldwide. Two abnormal shocks in global economic graphs are strongly distinctive: one appeared in 1973-1974, and the other arose in 19791980. These shocks stemmed from two events occurring in the MENA region: the 1973's October (Yom Kippur) War and the 1979's Iranian Revolution. Using event study methodology to analyze the impact of conflict on a selection asset markets, Guidolin and La Ferrara (2010) find that the Middle East is very important for commodity indices including oil prices as $73 \%$ of conflicts occurring in this region have an impact on oil futures, and this impact is distinguishable from zero.

1 UNHCR. (2018, May 25). Figures at a Glance. Retrieved from: http://www.unhcr.org/figures-at-aglance.html 


\section{Why Is It Important to Study Civil Conflicts through Regional Context?}

The MENA countries are connected geographically, economically, and culturally showing a strong tendency for connectedness and contagion. The famous words of Elias Hrawi, the former President of Lebanon, when describing the civil conflicts in his home: "it was not our conflict, but others' in our land," attest to this (Atallah, 2008: 217). Therefore, one cannot investigate any civil conflict there in isolation from the regional context. This political and security interference is not just because of the common borders, but also because of the strong connections of their people where the majority hold similar beliefs, culture, and religion and share the same history.

The historical and cultural roots of connectedness are too deep and long. During the thirteen centuries preceding WWI, the majority of the region's territories were controlled by different powers that ruled through one ideology, Islam. The Ottoman Empire was the last great state controlling the region. Its fall finished the Caliphate and paved the way to construct modern artificial countries that host people sharing a common history, culture, alphabet, feelings and demographical connections including tribal relationships. Heydemann, as quoted in Yousef (2004: 95), points out that, "the region's exceptionalism is a recent phenomenon and in no sense a cultural one derived from intrinsic beliefs, values and norms in Arab-Muslim societies." These sharing values and senses prevent the creation of different identities in new-born societies, hence they validate Anderson's theory of 'imagined communities' (Anderson, 2006); communities within the Middle East are similarly produced, and engineer similar power hierarchies between them, leading to a strong collective imagining.

The establishment of the MENA modern states by the end of WWI explains the main part of this connectedness. The Allies, who won WWI, including Britain and France, divided the Arabic territories formerly occupied by the Ottoman Empire. Later, these colonial powers would create the key structures and the public management of the new states. Owen (2013: 9) discusses this development:

\footnotetext{
"As far as the Middle East was concerned, it was generally the dominant colonial power that first created the essential features of a modern state, by giving it a centralized administration, a legal system, a flag and internationally recognized boundaries. In some cases this was done on the basis of some pre-existing administrative entity, as in Algeria; in others it involved either detaching a part of a former Ottoman province (for example, Trans-Jordan) or, more usually, adding several provinces together (for example, Syria and Iraq). This gave many of the new states a somewhat artificial appearance, with their new names, their new capitals, their lack of ethnic homogeneity and their dead-straight boundaries that were so obviously the work of a British or French colonial official using a ruler."
}

These new states, with ill-defined nature (Milton-Edwards and Hinchcliffe, 2007), host people that belong to different ethnic, linguistic, and religious groups. Barakat said that 
"[c]ertain communities were imposed on others within the same country" (1993: 6). One year after the civil conflict erupted in Lebanon, Anne Sinai and Chaim Waxman argued in the introduction to the Middle East Review (1976: 5):

\begin{abstract}
"[T]he current civil war in Lebanon is but the latest and most publicized in a broad range of events and situations which belie the contention that the Middle East is a unitary world of Arabs with a common background, culture, language and identity. The Middle East in fact consists of an intricate mosaic of different peoples... There are Shi'ites... Alawites, Druze, Yazidis, Isma'ilies and followers of various other Muslim denominations, who cling determinedly to their own style of faith and their own set of beliefs. They are not even necessarily ethnically 'Arab,' being the descendants of many different peoples conquered and converted by the Islamic armies... The first of the three great monotheistic religions, Judaism, and the people with whom it is identical, have been part of the Middle East mosaic from their beginning... There are, in addition... other small religious groupings, each clinging to its own distinctive identity. No Arab state, thus, can claim societal homogeneity and all consist of major and minor religious, linguistic and ethnic groupings."
\end{abstract}

This heterogeneity created socially and culturally incomplete entities where ethnic and religious groups, as well as tribes and families, were divided between adjacent countries. Religious heterogeneity dominates other types of heterogeneity in the region. This heterogeneity has been coupled with discriminative procedures towards minorities. Fox (2013) finds that almost all the religious minorities in 17 Middle Eastern Muslim majority states experience religious discrimination. The literature shows that this discrimination, as well as other sorts of persecutions, can provoke surrounding countries to intervene in other countries to protect their ethnic kin (Saideman, 2001; Trumbore, 2003; Woodwell, 2004). Svensson (2013) finds a massive shift from nonreligious to religious conflict in the MENA region, making it the world region where religious armed conflict is most prominent. Svensson (2013) also argues that religious conflict in the MENA is long and transitional.

Furthermore, current economic ties, especially employment, support the social and cultural roots and make people of different MENA countries more connected. Millions of the migrant MENA labor force work in the rich Gulf countries, and their remittances support their families and their governments in their homelands. These remittances are not only financial but also social, meaning that migrants transfer new ideas, values, and behavior to their home countries (Levitt, 1998) having an influence on political attitudes and behavior of families staying in the homelands. Investigating the diffusion of political Salafism among Egyptians working in Saudi Arabia, Karakoç et al. (2017) find that the 
strongest support for the Nour Salafism Party came from individuals whose family members had immigrated to Saudi Arabia. ${ }^{2}$

Intra-trade and investment flows are other economic ties supporting Arabic connectedness. According to reports published by the Arab Monetary Fund (2017), many Arabic countries heavily rely on trading with other Arabic countries. Somalia, Djibouti, Jordan, Lebanon, Syria, Egypt, and Sudan export 91\%, 85\%, 50\%, 45\%, 40\%, 32\%, and $30 \%$ of their total exports respectively to other Arabic countries, while the intra-Arab investments jumped from 3\% to $15 \%$ of the total Arabic GDP between 2000 and 2008 due to oil-price booms.

Historical evidence confirms how much strong is the links between MENA countries, in particular, the Levante. We depict these strong connections by presenting two assassination murders happened in Summer 1951. On July 17, Riad Al-Solh, the first Prime Minister of Lebanon after independence, was assassinated in Amman, the capital of Jordan, by Micheal El-Deek, a Syrian person. Three days later, King Abdullah I, the first Jordanian King, was assassinated in Jerusalem by a Palestinian tailor. King Abdullah might have not been killed had he become a King of Iraq, as it was supposed. This point brings us to another important scope that confirms the strong regional links in the MENA. It is about tracing the lineages between elite families.

Genealogy is important between Arab tribes. Thus, it is key to understand the kinship between royal families in the region. Hussein bin Ali, Sharif of Mecca and the leader of Hashemites, allied with the British and rebelled against Ottomans. Two of his sons became kings: Faisal for Syria, and then Iraq, and Abdullah for Jordan. Another son, Ali, was the last King of Hejaz before he was defeated by his Ibn Saud, the founder of the Kingdom of Saudi Arabia.

We find a similar kinship but between Arabic political parties. Pan-Arabic nationalism parties have emerged during the last century, and many of them believes in the unity of Arabic countries. Take for example, Ba'ath Party in Syria and Iraq; Arab Socialist Union in Egypt; Popular Conference Party in Libya; and Socialist Party in South Yemen. All of these parties have been in power in their countries for years. Some had a friendly relation with others, and some were bad enemies. Ba'ath was the ruling parties in both Syria and Iraq, but the two factions were under strong conflict for decades.

Combined with soft budget constraints in the oil-exporting countries, these strong interconnections facilitate inter-country interventions. Above all, the military rule, common in most of the MENA countries, intensifies this trend. The domination of military rule over national political system in the region can be proved by the large number of military coups and revolutions. Milton-Edwards and Hinchcliffe (2007: 4) point that this "militaristic nature of the state in the region has a direct cause-and-effect relationship on the political processes of countries" there, and Picard (1993) argues that the statist preferences, mass politics, and anti-colonial struggles which existed in the post-Ottoman Middle East, lead to strong involvement of the military in politics. Those military governments appear to operate according to a logic of expansion and hence intervene in the political life of neighboring states.

2 Nour Salafism Party, which means Party of The Light, is one of the political parties created in Egypt after the 2011 Egyptian Uprising. It has an ultra conservative Islamist ideology, which believes in implementing strict Sharia law. 


\section{Final Remarks}

Watching daily news, the western observer is becoming aware of the violence appeared in the MENA region. Indeed, Karl Remarks' statement: "and then God created the Middle East and said, let there be breaking news and analysis", which became the title of his recent book published in 2018, attests to this. However, the western observer might be confused by the high degree of connectedness between these violent events. The current note, therefore, tries to shed light on the reasons behind this connectedness. It followed a multidisciplinary approach to explain why the domino effect has appeared in the region and why we should look at conflicts there, including civil wars, from a regional perspective.

It is important, before closing this note, to mention two important points. First, although unique as discussed in this note, the MENA region is a part of the Third World, hence it is subject to the same universal process of underdevelopment as other Third World countries, and one should put that in his mind when investigating conflicts there. In the preface of his book, Owen warns researchers not to explain everything happening in the MENA "by the fact that the majority of its people are Arab or Muslims who, until becoming rich from oil, lived as tribes in deserts" (2013: xii). Looking deeply at other conflicts in other regions of the world, for example, Sub-Saharan Africa, South Asia, the Balkans, and Latin America, many similarities can be seen within the reasons and consequences of civil conflicts.

Secondly, scholars should not ignore the specific characteristics of individual MENA countries. These countries are heterogeneous in terms of both economic and institutional development. One can easily notice this by skimming the economic figures and, more importantly, the human development index (UNDP, 2018). While all GCC countries are classified as very highly developed, Syria, Sudan, Yemen, Djibouti, Somalia, and Mauritania are classified in the lowest rank.

\section{References}

Al-Hussein. Z., R., (2017, March 14). A statement by the UN High Commissioner for Human Rights, Zeid Ra'ad Al Hussein. Retrieved from: https://news.un.org/en/story/2017/03/553252-syria-worst-man-made-disaster-worldwar-ii-un-rights-chief

Anderson, B. (2006). Imagined communities: Reflections on the origin and spread of nationalism. Verso Books.

Arab Monetary Fund. (2017). Statistics of inter and intra Arab trade competitiveness. Abu Dhabi. Retrieved from: http://www.amf.org.ae/en/page/statistics-inter-and-intraarab-trade-competitiveness

Atallah, S. (2008), Makal Al-Arbe'a: Mokhtarat etebaran men al-am alfeen [Wednesday Article: Selections since 2000]. Dar Al-Saki, Beirut. ISBAN: 1855169789.

Barakat, H. (1993). The Arab world: Society, culture, and state. University of California Press.

Brown, L. C. (1984). International politics and the Middle East: Old rules, dangerous 
game. IB Tauris.

Cevik, S., and Rahmati, M. (2015). Breaking the curse of Sisyphus: an empirical analysis of post-conflict economic transitions. Comparative Economic Studies, 57(4), 569-597.

Collier, P. (2007). The Bottom Billion: Why the poorest countries are failing and what can be done about it: Oxford University Press.

Davison, R. H. (1960). Where is the Middle East? Foreign Affairs, 38(4), 665-675.

Fox, J. (2013). Religious discrimination against religious minorities in Middle Eastern Muslim states. Civil Wars, 15(4), 454-470.

Guidolin, M., and La Ferrara, E. (2010). The economic effects of violent conflict: Evidence from asset market reactions. Journal of Peace Research, 47(6), 671-684.

Hudson, M. (1976). The Middle East. In J. Rosenau (Ed.), World Politics (pp. 476-500). New York: Free Press.

Johannsen, M. (2009). Der Nahost-Konflikt [The Middle East Conflict]. VS Verlag für Sozialwissenschaften.

Karakoç, E., Köse, T., and Özcan, M. (2017). Emigration and the diffusion of political Salafism: Religious remittances and support for Salafi parties in Egypt during the Arab Spring. Party Politics, 23(6), 731-745.

Levitt, P. (1998). Social remittances: Migration driven local-level forms of cultural diffusion. International Migration Review, 32(4), 926-948.

Marshall, A. (2016). From civil war to proxy war: past history and current dilemmas. Small Wars \& Insurgencies, 27(2), 183-195.

Milton-Edwards, B., and Hinchcliffe, P. (2007). Conflicts in the Middle East since 1945. Routledge.

Nerguizian, A., and Kasting, N. (2013). US-Iranian Competition in the Levant-II. Washington DC: Center for Strategic and International Studies.

Owen, R. (2013). State, power and politics in the making of the modern Middle East. Routledge.

Özalp, O. N. (2011). Where is the Middle East? The Definition and Classification Problem of the Middle East as a Regional Subsystem in International Relations. Turkish Journal of Politics, 2(2), 5-21.

Picard, E. (1993). La nouvelle dynamique au Moyen-Orient: les relations entre l'Orient arabe et la Turquie [The new dynamic in the Middle East: relations between the Arab East and Turkey]. Editions L'Harmattan.

Posen, B. R. (1996). Military responses to refugee disasters. International Security, 21(1), 72-111.

Ross, M., Kaiser, K., and Mazaheri, N. (2011). The resource curse in MENA? political transitions, resource wealth, economic shocks, and conflict risk. The World Bank.

Rother, M. B., Pierre, M. G., Lombardo, D., Herrala, R., Toffano, M. P., Roos, M. E., and Manasseh, M. K. (2016). The Economic Impact of Conflicts and the Refugee Crisis in the Middle East and North Africa. IMF Staff Discussion Note No. 16/08. The International Monetary Fund. 
Saideman, S. M. (2001). The ties that divide: Ethnic politics, foreign policy, and international conflict. Columbia University Press.

Salehyan, Idean. (2008). The externalities of civil strife: Refugees as a source of international conflict. American Journal of Political Science, 52(4), 787-801.

SCPR. (2016). Confronting Fragmentation. Syrian Center for Policy Research, Beirut. Retrieved from: http://scpr-syria.org/publications/confronting-fragmentation/

Sinai, A., and Waxman, C. (1976). Middle East Review, 9(1), 5.

Steinbach, U. (1979). Politisches Lexikon Nahost [Political lexicon Middle East]. München: Beck.

Svensson, I. (2013). One God, many wars: Religious dimensions of armed conflict in the Middle East and North Africa. Civil Wars, 15(4), 411-430.

Tibi, B. (1989). Konfliktregion Naher Osten. Regionale Eigendynamik und Großmachtinteressen [Conflict region Middle East. Regional momentum and major interests]. München: Beck.

Trumbore, P. F. (2003). Victims or Aggressors? Ethno-Political Rebellion and Use of Force in Militarized Interstate Disputes. International Studies Quarterly, 47(2), 183-201.

Tunçdilek, N. (1971). Güneybatı Asya. [Southwest Asia]. İstanbul: İstanbul University. Yay.

UNDP. (2014). Human development report 2016: Human Development for Everyone. United Nations Development Programme.

UNHCR. (2018, May 25). Figures at a Glance. Retrieved from: http://www.unhcr.org/figures-at-a-glance.html

Uppsala University. (2015). UCDP/PRIO Armed Conflict Database Version 4, 2015 UCDP. Uppsala, Sweden: Department of Peace and Conflict Research.

Walter, B. F. (2015). Why bad governance leads to repeat civil war. Journal of Conflict Resolution, 59(7), 1242-1272.

Woodwell, D. (2004). Unwelcome neighbors: shared ethnicity and international conflict during the Cold War. International Studies Quarterly, 48(1), 197-223.

Yousef, T. M. (2004). Development, growth and policy reform in the Middle East and North Africa since 1950. The Journal of Economic Perspectives, 18(3), 91-115. 